\title{
DO MONOLINGUISMO À DIGLOSSIA: A LÍNGUA UCRANIANA EM PRUDENTÓPOLIS-PR AO LONGO DO SÉCULO XX
}

\author{
From Monolingualism to Diglossia: The Ukrainian Language \\ in Prudentópolis - Pr Throughout The 20th Century
}

\section{Lourenço Resende da Costa*}

\begin{abstract}
RESUMO: Nesse artigo, o objetivo foi discutir como a língua ucraniana pôde ser usada para caracterizar a identidade etnocultural dos descendentes de ucranianos em Prudentópolis, Paraná, ao longo do século XX. Para tanto, foi analisado como, de uma situação monolíngue, os imigrantes e seus descendentes passaram a se comunicar de modo bilíngue até que uma situação de diglossia se caracterizasse. Junto à análise das questões teóricas acerca do monolinguismo, bilinguismo e diglossia, foram utilizadas fontes orais para melhor compreensão do fenômeno ao longo do século passado no município paranaense. Constata-se que mesmo o idioma ucraniano sendo cada vez menos falado em Prudentópolis continua representando um fator de identificação entre as pessoas que possuem a ascendência.

Palavras-chave: Prudentópolis-PR; Língua ucraniana; Identidade.
\end{abstract}

\begin{abstract}
In this article, the objective was to discuss how the Ukrainian language was used to characterize the ethnocultural identity of the descendants of Ukrainians in Prudentópolis, Paraná, throughout the 20th century. For that it was analyzed how, from a monolingual situation, immigrants and their descendants started to communicate in a bilingual way until a situation of diglossia was characterized. Along with the analysis of theoretical questions about monolingualism, bilingualism and diglossia, oral sources were used to better understand the phenomenon over the past century in the municipality of Paraná. And even the Ukrainian language, being less and less spoken in Prudentópolis, continues to represent an identification factor among people who have this ancestry.
\end{abstract}

Keywords: Prudentópolis-PR; Ukrainian language; Identity.

As dificuldades de comunicação, bem como as identificações em razão da língua, não são exclusividade de um povo, um período ou um recorte espacial. Na Idade Média, sobretudo no primeiro milênio da era cristã, latim, grego e hebraico eram considerados línguas de cultura, pois com eles a Bíblia, tratados, anais e textos eclesiásticos eram escritos; serviam também para a comunicação oficial dentro de um mesmo reino ou entre diferentes governos (DECROSSE, 1989, p. 20).

Contudo, a utilização do grego ou latim na documentação oficial, não significava que a população ou mesmo o governante de uma região os falasse cotidianamente. Por isso, a linguagem está intimamente associada à questão do poder (DECROSSE, 1989, p. 19). O surgimento e o sucesso de ideais nacionalistas no século XIX se deram, em grande medida, a partir do momento em

\footnotetext{
* Doutor em História pela UFPR. Secretaria de Estado da Educação do Paraná - SEED. E-mail: resendedacosta@gmail.com
} 
que os vernáculos locais se sobressaíram. A utilização de outros idiomas além do latim em publicações de toda natureza também está em acordo com o avanço da economia capitalista, que busca mercados populares (ANDERSON, 2008, p. 73).

Com o crescimento do uso dos vernáculos, no final da Idade Média, o latim e o grego foram perdendo sua condição de universalidade e, à medida que o mundo foi caminhando lentamente para contatos cada vez mais globais, a comunicação tornou-se um problema (PASSINI, 1993, p. 19).

No século XIX, período do surgimento e consolidação de diversos nacionalismos e de grandes ondas migratórias para diversas partes do mundo, a língua não era um empecilho intransponível para que as fronteiras nacionais fossem definidas. As pessoas que falavam determinado idioma se identificavam com mais facilidade com aquelas que também o falavam, mas a ideia de uma língua "nacional" falada, ágrafa ou diferente das "línguas de cultura", não era simples de se efetivar (HOBSBAWM, 1990, p. 69).

Em contextos de imigração a língua adquire uma relevância especial, uma vez que influencia o sucesso do contato interpessoal no local de destino. Mas o abandono, total ou parcial, da identidade trazida do lugar de origem não é imediato ou desejável na maioria dos casos. Quando a dificuldade de comunicação surge nesses contextos, o bilinguismo aparece como uma tática possível. Para Certeau (1994, p. 46) a tática é o expediente de quem, numa relação de forças, está do lado mais fraco. $\mathrm{Na}$ sociedade receptora, esse era, muitas vezes, o polo em que estavam os imigrantes.

Mas, a tese do monolinguismo não se sustenta, pois é empiricamente difícil (para não dizer impossível) apontar um país ou região que não possua variações na língua falada ou em que não existam diferenças entre o oral e o escrito. Dentro de um ambiente em que há diversos códigos linguísticos, pode-se incorrer no erro de buscar o modo "mais correto", em uma tentativa de hierarquização (BAGNO, 2001, p. 16). No Brasil, somente na Constituição de 1988 a sociedade brasileira foi reconhecida como plurilíngue (MARTINY; MENONCIN, 2013, p. 302).

No que se refere aos imigrantes que se instalaram no Brasil ao longo do século XIX e da Primeira República, o aprendizado do português era uma necessidade social e prática; daí a prática do bilinguismo ser uma realidade em diferentes áreas e com grupos de origens distintas. Os alemães, em alguma medida, por exemplo, mantiveram a língua nas colônias formadas - a maior parte ainda no século XIX - nos três estados do Sul (SEYFERTH, 2003, p. 21). A linguagem entre os alemães também é uma questão complicada, pois as pessoas de origem germânica que desembarcaram no Brasil eram oriundas de diferentes regiões, cada qual com um dialeto próprio. Até o início da década de 1870 a Alemanha como país unificado não existia; os alemães que chegaram ao Brasil eram prussianos, pomeranos, silesianos, entre outros (NADALIN, 2007, p. 14).

Os imigrantes alemães, principalmente nos estados do Rio Grande do Sul e Santa Catarina, mas também no Paraná, se alocaram em regiões pioneiras e de difícil contato com centros maiores. Além disso, o governo imperial não realizou maiores esforços para a integração real desse grupo à sociedade luso-brasileira. Por essa razão, eles desenvolveram sua organização social à parte, embora evidentemente em contato com a sociedade nacional (SEYFERTH, 2003, p. 38).

Os alemães, assim como outros grupos imigrantes, diante da precariedade, insuficiência ou completa inexistência de escolas públicas, realizaram sua própria política educacional. Assim, esses imigrantes, muito antes das leis de nacionalização do ensino na Era Vargas, já buscavam aprender o português em suas escolas (LUNA, 2000, p. 113). Isso contraria os rumores sobre o "perigo alemão", termo usado para designar a dificuldade destes em se integrarem à sociedade brasileira; acusação discutível, uma vez que o governo brasileiro não oferecia aos imigrantes as condições para que tal integração se efetivasse (SEYFERTH, 2003, p. 36). 
Por sua vez, os poloneses, com presença importante no Paraná, experimentaram a liberdade no Brasil: "Rejubilavam-se por terem aqui um sossego ilimitado e poderem girar livremente pela terra de Cabral, servindo-se como bem entendessem da língua que trouxeram consigo" (WACHOWICZ, 2002, p. 23). Mas, da mesma forma que os alemães, eles não receberam a devida atenção e estrutura dos governos imperial e republicano, tanto no âmbito nacional como provincial/estadual. A partir de 1920 as línguas estrangeiras passaram a sofrer restrições e proibições (RENK, 2009).

Dessa forma, percebemos que a tentativa de manutenção da língua trazida da Europa e a consequente tática do bilinguismo não é exclusividade dos ucranianos. Os alemães, no entanto, não sofriam, no continente europeu, repressão em razão da sua fala. Essa é uma diferença fundamental em relação à etnicidade ucraniana ligada ao idioma. Os poloneses, por sua vez, embora sofressem algum tipo de repressão linguística pelo governo austríaco ou russo, ainda possuíam certa supremacia em relação aos ucranianos (ANDREAZZA, 1996, p. 16).

Por essa razão, a língua, no nosso entendimento, é tão importante na construção e reconstrução da etnicidade ucraniana. Nesse contexto, a permanência da língua, ou ao menos a luta para que ela persista, possibilita o uso simultâneo e/ou intercalado dos dois idiomas e, nesse processo, a identidade étnica vai sendo delineada. Neste texto, o termo bilinguismo está sendo utilizado em referência à "aprendizagem de uma segunda língua ou a aquisição simultânea de duas línguas pelas crianças” (DE HEREDIA, 1989, p. 183).

Esse tipo de situação foi/é muito comum na história de Prudentópolis ${ }^{1}$ : muitas crianças cresceram utilizando tanto a língua ucraniana como a portuguesa. $O$ aprendizado do português não eliminou a língua eslava e, mesmo dominando o vernáculo nacional de modo adequado, é comum que estes falantes optem pelo ucraniano em diversas situações.

É longa a discussão do que seja uma pessoa bilíngue: primeiramente se atribuía esta condição ao indivíduo que dominava totalmente dois sistemas linguísticos; posteriormente, o bilíngue, para ser considerado como tal, deveria utilizar alternadamente e de modo satisfatório duas línguas, frisando-se ainda que não poderia haver influência de uma sobre a outra; posteriormente, o bilíngue seria aquele que conseguisse utilizar dois idiomas diferentes em graus variáveis, sendo esta uma condição individual (MARTINY; MENONCIN, 2013, p. 306-307).

O bilinguismo a que nos referimos é a capacidade de utilização da língua ucraniana e da língua portuguesa, ainda que alguns descendentes de imigrantes dominem de forma plena o ucraniano e outros não. A prática bilíngue foi adotada por muitas pessoas em Prudentópolis em razão das necessidades cotidianas, em um contexto de crescente utilização do português nos últimos cem anos. A manutenção da língua e o esforço em continuar falando o ucraniano são fortes sinais da sua importância para a delimitação do grupo étnico.

No município o bilinguismo adquire uma conotação especial, uma vez que a insistência no uso do ucraniano está ligada ao aspecto étnico definidor do grupo. As mútuas interferências linguísticas e as mudanças ao longo do tempo na relação entre o ucraniano/português - português/ucraniano demonstram que a manutenção do idioma eslavo é consciente, o que evidencia,

\footnotetext{
1 Prudentópolis está localizado no sudeste do Paraná, os territórios do atual município começaram a ser colonizados no século XIX a partir da expectativa da passagem de uma linha telegráfica pela região. Na época os territórios prudentopolitanos integravam o município de Guarapuava. A emancipação ocorreu em 1906. Na última década do século XIX, chegou um grande contingente de imigrantes eslavos na colônia criada para recepção dos colonos. A maioria dos recém-chegados possuía ascendência ucraniana. Atualmente o município possui economia voltada principalmente para a agricultura e no último censo oficial contou pouco mais de 48 mil habitantes, sendo que um pouco mais da metade residindo na área rural (COSTA, 2013, p. 55).
} 
mais uma vez, que a fronteira étnica se dá no contato e não no isolamento (BARTH, 2011).

Ogliari (1999) analisou a vitalidade da língua ucraniana, minoritária, frente à língua portuguesa, majoritária, em Prudentópolis no final do século XX. A vitalidade do ucraniano, segundo ela, se manteve ao longo do século XX em função do número significativo de usuários e do suporte institucional da Igreja Ucraniana, bem como do contexto de formação das comunidades, em que havia certa supremacia numérica de pessoas com ascendência ucraniana. Ao longo de mais de um século de presença ucraniana no município, o bilinguismo foi uma tática usada pelos descendentes dos pioneiros para a manutenção do seu idioma frente ao crescente avanço do idioma nacional do Brasil sobre a prática cotidiana da língua ucraniana. Com isso se conciliava a necessidade do aprendizado da língua nacional e o uso do idioma dos ancestrais ${ }^{2}$.

No Paraná, a língua ucraniana, juntamente com as línguas de outros grupos imigrantes, sofreu com as proibições varguistas; nesse caso a tática foi o bilinguismo, como forma dos alunos continuarem usando o idioma trazido da Europa. Era esse um dos motivos centrais para a sobrevivência das escolas étnicas. A linguagem era o pilar desses estabelecimentos escolares: sem ela não haveria justificativa para sua existência, pois, sem o uso do vernáculo, qualquer escola nacional serviria (RENK, 2009, p. 101). Portanto, a linguagem utilizada nesses locais de ensino fazia parte de uma etnocultura que atravessou o Atlântico e é parte constituinte da identidade ucraniana (re)construída no Brasil.

Para Achard (1989, p. 41-42), ao estabelecer as diretrizes do ensino escolar obrigatório, o governo procura fazer do monolinguismo o padrão nas escolas. Isso ocorre porque um sistema público de ensino busca, muitas vezes, eliminar as diferenças. O que as políticas de ensino no Estado Novo objetivavam era justamente essa padronização escolar/linguística. Por sua vez, Poche (1989, p. 75) afirma que o monolinguismo corresponde ao mito de uma sociedade que fala um idioma sem nenhuma variação.

No contato entre os falantes e os não falantes do ucraniano, as fronteiras são erguidas e, concomitantemente, retraçadas, possibilitando novos contatos ao longo do tempo. Os grupos vão sendo (re)definidos e também podem surgir as "crises de identidade". Portanto, a língua é viva e transforma e é transformada na relação com o diferente.

Em Prudentópolis a língua ucraniana perdeu o contato com as transformações pelas quais passou na Ucrânia. Por outro lado, em terras paranaenses as mudanças também não deixaram de ocorrer. No Brasil o ucraniano passou a coexistir com o português, e o bilinguismo propiciou o "aportuguesamento" de algumas palavras. A adoção de palavras ucranianas em conversas em português e palavras portuguesas em diálogos no idioma eslavo é comum:

São novas palavras criadas para suprir uma necessidade imediata dos falantes da língua ucraniana, termômetro para medir a forma de interação verbal daquelas pessoas que não deixaram de falar a sua língua de imigração, termos que nasceram do hibridismo das línguas portuguesa e ucraniana. (SIMIONATO, 2012, p. 41).

No município de Prudentópolis as pessoas que falavam a língua ucraniana, no seu

\footnotetext{
2 Para Michel de Certeau (1994, p. 47), a estratégia é prerrogativa de instituições, pessoas ou grupos que detêm poder. Por exemplo, durante o governo Vargas, instituições com poder usaram a estratégia da proibição do uso exclusivo de línguas estrangeiras nas escolas. A tática, por outro lado, conforme já dito anteriormente, é expediente dos fracos, daqueles que sofrem as consequências das estratégias dos detentores do poder. A partir da tática as pessoas comuns, em seu cotidiano, resistem às imposições. 0 bilinguismo foi uma forma de obedecer à lei e ao mesmo tempo subverter sua lógica.
} 
progressivo contato com a língua portuguesa ao longo das gerações, proporcionaram transformações e adaptações ao ucraniano. Transformações essas que ocorreram de maneira diferente das ocorridas na Europa, pois aqui seus interlocutores utilizavam a língua portuguesa.

Outra característica é o sotaque. A maneira de sonorizar as palavras é fruto do uso das duas línguas e pode auxiliar na identificação dos descendentes de ucranianos (claro que isso também ocorre com pessoas que falam outros idiomas e o português alternadamente, além dos regionalismos). O uso de palavras ucranianas como "máma" e "táto", mãe e pai, respectivamente, por exemplo, ajuda a acentuar essa identificação ${ }^{3}$.

Portanto, a inflexão da voz, resultado do uso concomitante e/ou sequencial do ucraniano e do português, embora não seja exclusividade de quem possui ascendência ucraniana, é, em Prudentópolis, um forte indício de pertencimento etnocultural. A pronúncia pode ficar tão marcada a ponto de algumas pessoas, principalmente os jovens, não buscarem cultivar a "tradição", por se sentirem de alguma forma estigmatizados. $\mathrm{O}$ fato pode ser atribuído à questão geracional, pois pais e avós nasceram e cresceram em um contexto em que o idioma trazido da Ucrânia era falado tanto em casa como em lugares públicos. Para as pessoas mais velhas era, muitas vezes, mais fácil conversar usando o idioma da terra de origem dos antepassados. Mas é evidente que essa situação da "vergonha" ou do estigma em razão do sotaque não pode ser generalizada em demasiado. Da mesma forma que sentir vergonha não é sinônimo de negação da etnocultura, a identidade étnica, na perspectiva barthiana, pode ser exaltada ou ocultada conforme a necessidade e/ou situação vivida pelo indivíduo (VILLAR, 2004, p. 182).

O bilinguismo também ocorre na religião, um dos principais suportes de manutenção da língua ucraniana, pois o Evangelho, as orações, cantos, homilia e praticamente toda a cerimônia religiosa, excetuando avisos gerais, são falados no idioma eslavo. Mas, mesmo nesse "refúgio", ele começa a dar cada vez mais espaço ao português. A homilia na Igreja Ucraniana, normalmente, possui duas versões: primeiramente o sacerdote faz uma versão em língua ucraniana e, posteriormente, faz o "sermão" em língua portuguesa.

A Igreja Greco Católica Ucraniana de Rito Bizantino é responsável, em grande medida, pela língua ucraniana permanecer viva em Prudentópolis. No entanto, mesmo esse baluarte, após mais de cem anos da imigração ucraniana para o Brasil, começa a ser invadido pelo bilinguismo e a sofrer a pressão para que as celebrações litúrgicas sejam traduzidas (SKAVRONSKI, 2015, p. 14).

No período do Estado Novo, falar as duas línguas era uma tática frente às pressões do governo e/ou diante dos contatos cotidianos com pessoas monolíngues em língua portuguesa. Em 1939, o Decreto $n^{\circ} 1545$ proibia que idiomas estrangeiros fossem utilizados em público e mesmo em cerimônias religiosas (GUÉRIOS, 2007, p. 218). Ao longo das décadas esse bilinguismo pode ser considerado uma forma de resistência, uma necessidade diante do crescente avanço da língua vernácula sobre o eslavo. No âmbito religioso, o uso da língua portuguesa, ainda que em momentos específicos da celebração litúrgica, como na homilia e nos avisos gerais, é um modo de articular a "tradição" com as novas necessidades e não afastar as gerações mais jovens. Assim como privilegiar a mensagem cristã.

A tradução da celebração para a língua portuguesa, ou de apenas algumas de suas partes, é uma questão a ser enfrentada pelos dirigentes da Igreja Ucraniana em Prudentópolis, assim como

\footnotetext{
3 É preciso reforçar que o objetivo neste texto não é analisar as mudanças estruturais da língua, campo por excelência dos gramáticos e linguistas.
} 
de outras paróquias ucranianas no Brasil. Não existe um consenso sobre o assunto. Os mais jovens não compreendem muito daquilo que é dito pelo sacerdote e respondido pela assembleia (principalmente pelas pessoas mais velhas). Porém, suprir a carência dos mais jovens esbarra na resistência dos fiéis de gerações mais velhas ${ }^{4}$.

Para Ogliari (1999, p. 29-30), a língua ucraniana utilizada em Prudentópolis pode ser classificada como etnorreligiosa, uma vez que o idioma está intimamente ligado à religião e é mantido em função do seu uso na liturgia. A Igreja Ucraniana, conforme já apontado, é responsável em grande medida pela sobrevivência do idioma trazido pelos primeiros imigrantes no Brasil e, de modo particular, em Prudentópolis. Mas, como também já ressaltado, a língua portuguesa avança sobre esse sustentáculo da língua ucraniana. Dependendo da comunidade e do sacerdote que celebra a missa, o português invade mais ou menos a liturgia.

A prática do bilinguismo, portanto, está no limite entre a necessidade e a resistência. No passado mais longínquo, leia-se nas primeiras décadas da chegada dos ucranianos ao Brasil ${ }^{5}$, ele era uma ferramenta utilizada para manter o idioma trazido da terra natal diante da urgência do aprendizado da língua vernácula do país de destino, assim como uma tática usada para enfrentar as restrições do Estado Novo. Ao mesmo tempo em que obedeciam às imposições estado-novistas, mantinham sua identidade etnocultural.

Por outro lado, em tempos mais recentes, o bilinguismo é uma resistência ao crescente abandono da língua dos antepassados. As gerações mais jovens já não aprendem em primeiro lugar a língua ucraniana e não convivem quase exclusivamente com falantes do ucraniano. O bilinguismo de necessidade passa a uma condição de resistência e também denota contexto de diglossia.

O termo diglossia passou a ser usado na discussão acerca da situação linguística na Grécia após sua independência frente ao Império Otomano. Entre os gregos, o conceito era usado para distinguir os usos formais e informais do idioma (LINHARES; ALENCAR, 2016, p. 495). Portanto, a diglossia foi usada para distinguir, nos estudos linguísticos, situações em que uma língua falada tinha diferenças com sua norma escrita. Essas discrepâncias podiam ser maiores ou menores, dependendo do caso:

[...] empregava-se um código linguístico em âmbitos formais ao qual se pode chamar "variedade alta" ou "A" (o grego padrão, o árabe padrão, o alemão padrão e o francês padrão) e outros códigos linguísticos em âmbitos informais a cujo conjunto se pode chamar "variedade baixa" ou "B" (o grego vernáculo, o árabe vernáculo, o alemão vernáculo e o crioulo). (LINHARES; ALENCAR, 2016, p. 498-499).

A diglossia foi primeiramente pensada para distinguir variantes de uma mesma língua, mas posteriormente foi também utilizada para analisar situações em que idiomas distintos convivem, um deles exercendo posição de maior prestígio.

Ferguson cingira a diglossia ao uso coordenado de dois códigos por uma mesma comunidade quando esses dois códigos são variedades da mesma língua. Fishman defende que a diglossia acontece independentemente dos estatutos dos códigos coordenados, ou seja, ele ampliou a

\footnotetext{
4 Exemplo desse debate é encontrado no trabalho de Jacumasso (2009, p. 103). O autor cita o caso de um sacerdote e de um fiel da Igreja Ucraniana da comunidade de Itapará, zona rural do município de Irati, que discordaram a respeito da tradução nas celebrações religiosas na igreja da localidade. O sacerdote salientava o fato das traduções suprirem a falta de compreensão dos jovens, sendo uma forma de não os afastar da igreja. O paroquiano, de uma geração mais antiga, se colocava contrário ao uso da língua portuguesa.

5 Final do século XIX e início do século XX.
} 
aplicação do conceito. Da perspectiva de Fishman, a sociedade do Paraguai, onde o espanhol desempenha os papéis de uma variedade alta e o guarani, os de uma variedade baixa, é tão diglóssica quanto as sociedades dos países árabes. (LINHARES; ALENCAR, 2016, p. 501).

De acordo com os pesquisadores que estudam contatos linguísticos há uma diferença entre o bilinguismo e a diglossia. O primeiro é fruto de uma situação individual, enquanto a segunda deriva de um contexto sociocultural:

Isso não quer dizer que o bilinguismo não seja social segundo o entendimento de Fishman. Quer dizer que a diferença entre o bilinguismo e a diglossia está sobretudo no fato de que nesta os usos dos códigos implicados são pautados por diferentes funções sociais. Para Fishman, o bilinguismo e a diglossia podem, pois, ocorrer de forma exclusiva ou podem coocorrer. (LINHARES; ALENCAR, 2016, p. 501).

Seguindo a perspectiva de Fishman, Lopes (2011, p. 128) defende que a diglossia não ocorre somente na variação formal e informal de uma mesma língua. Em nosso caso empírico, podemos verificar que nas primeiras décadas do século $\mathrm{XX}$ as pessoas viviam em um contexto bilíngue, enquanto mais recentemente passaram para uma situação diglóssica. Isso porque o ucraniano, mesmo sendo a língua materna de pais e avós, deixou de ser o primeiro idioma aprendido por filhos e netos. Mesmo para indivíduos nascidos nos anos 1990 e 2000 que ainda aprenderam primeiro o ucraniano a situação logo mudou devido ao contexto. A língua portuguesa domina cada vez mais os documentos formais, a maioria dos veículos de comunicação de massa, a escola, etc.

Em uma situação de diglossia, de acordo com Lopes (2011, p. 129), a língua materna é sempre a língua com menor prestígio social ou aquela que não é a língua padrão da sociedade em foco. Além disso, a "variante alta" ou de prestígio é adquirida na escola, e não no ambiente doméstico (LINHARES; ALENCAR, 2016, p. 499).

Martiny e Menoncin (2013) ponderam que tanto Ferguson como Fishman desconsideram os conflitos e privilegiam a homogeneidade nos contatos entre falantes de distintos códigos linguísticos. Elas defendem que os contatos entre pessoas que utilizam diferentes línguas devem ser analisados sob uma perspectiva assimétrica: "Quando se pensa em diglossia, há a visão de que uma língua é superior e as outras são subordinadas a esta. Mas o que uma teria de melhor ou pior do que a outra?" (MARTINY; MENONCIN, 2013, p. 312).

A partir da nacionalização das escolas étnicas houve a substituição das línguas dos imigrantes pela língua portuguesa, o que caracteriza uma situação diglóssica, se considerarmos que a partir do Estado Novo o português passou a ser obrigatório e exclusivo em um espaço antes aberto ao uso de outros idiomas.

No Brasil, em locais com grande número de imigrantes de uma mesma nacionalidade/etnia, a tendência observada foi a de que, no decorrer dos anos, as pessoas passaram de uma condição monolíngue na língua do país/região de origem para uma situação de bilinguismo e, posteriormente, para um progressivo abandono do idioma da terra natal em favor do português, o que caracteriza um contexto de diglossia.

O caso analisado não fugiu completamente a essa tendência. No entanto, os ucranianos não abandonaram completamente sua língua e continuam enxergando-a como fator que define sua etnicidade. Eles, ao longo de mais de 100 anos de presença em solo prudentopolitano, ainda se identificam enquanto grupo por usar a língua falada por seus antepassados, seja a partir do bilinguismo, em diferentes graus, ou mesmo em face da diglossia. 
A língua ucraniana possui uma história, evidentemente, anterior ao período da vinda de pessoas para o Brasil. Os primeiros imigrantes ucranianos que desembarcaram nos portos brasileiros pouco ou nenhum contato anterior haviam tido com a língua portuguesa. Por essa razão, a instalação de um número grande de pessoas de uma mesma região em uma mesma colônia se mostrou importante para a manutenção da identidade étnica. No entanto, mesmo gozando dessa condição, os ucranianos em Prudentópolis não estavam isolados de modo que não sofressem as consequências de utilizarem um idioma diferente do oficial do Brasil ${ }^{6}$.

Diante desse quadro, era comum que algumas pessoas fossem empregadas pelas companhias de imigração ou por agentes estatais para abertura de estradas e demarcação de lotes (ANDREAZZA, 1996, p. 50). O trabalho temporário assalariado em lavouras distantes da colônia era outra forma encontrada pelo imigrante para sustentar a família. Mas a língua era mais um fator complicador na hora de conseguir o emprego e se comunicar nessa ocupação intermitente (GUÉRIOS, 2007, p. 129).

Portanto, às experiências e descobertas cotidianas que os imigrantes viviam nos primeiros tempos de instalação no Brasil pode-se somar o choque/dificuldade em relação à língua, que acaba surgindo com menor ou maior ênfase. Exemplo disso pode ser tirado do texto autobiográfico de Basílio Burko (2010) em que ele narra sua viagem até Irati com o objetivo de pegar o trem para Curitiba, para prestar o serviço militar. Nessa viagem, realizada em 1921, ele precisou se hospedar em Irati-PR, junto com dois companheiros de viagem que também serviriam o exército, pois o trem que os levaria até Curitiba saiu antes que eles chegassem à estação ferroviária.

A dificuldade da língua poderia ter aparecido nessa ocasião, uma vez que eles não conheciam a cidade. Os viajantes conseguiram local para passar a noite em um sótão cedido por um comerciante. Não há especificação se a pessoa que cedeu o espaço era ucraniana, apenas que era da região da Galícia (BURKO, 2010, p. 16). Irati, assim como Prudentópolis, recebeu um número significativo de imigrantes de origem eslava. Mas lá a quantidade de poloneses foi maior.

A experiência relatada por Basílio não apresenta conflitos em razão da língua ou estranhamentos em razão de sua origem étnica. No entanto, nem sempre as coisas ocorriam de forma harmoniosa (importante ressaltar que Basílio está narrando sua história muitos anos depois dos fatos ocorridos). As informações da infância são mínimas, pois, após poucas páginas, ele já narra sua partida para o exército em 1921. Décadas mais tarde, ir para a escola, por exemplo, poderia significar um momento de choque étnico/linguístico.

No Paraná, sobretudo nas áreas rurais, muitas crianças continuavam chegando à escola falando apenas a língua do grupo étnico do qual descendiam. Em Prudentópolis, não raro, crianças chegavam à idade escolar falando apenas o ucraniano, mesmo após as restrições varguistas e várias décadas após o fim do Estado Novo.

Dona Genoveva, por exemplo, nasceu em 1947, frequentou a escola em meados da década de 1950 e não sabia nem dizer "bom dia!" em língua portuguesa ${ }^{7}$. Ela relatou que, quando chegou à escola, houve muita dificuldade no aprendizado do vernáculo nacional; essa dificuldade era amenizada porque a professora era bilíngue. Caso semelhante ao de Teodosio Tlumaski, nascido em 1946, Sofia Podogurski Hellmann, nascida em 1952, e Isabel Sydorko Bahry, nascida em 1938

\footnotetext{
${ }^{6}$ A escola foi uma das táticas usadas para que as crianças nascidas no Brasil não perdessem o contato com o idioma materno. Os ucranianos, de acordo com Renk (2009, p. 20), possuíam cerca de 60 escolas no ano de 1938, ano em que as políticas do Estado Novo decretaram o fim dessa modalidade escolar em favor de escolas monolíngues em português.

7 Todas as entrevistas foram realizadas com pessoas nascidas no Brasil.
} 
(COSTA, 2013, p. 59). Mas esse contato cultural não ficou restrito aos primeiros anos da chegada dos imigrantes, aos anos do governo de Getúlio Vargas ou às décadas imediatamente posteriores ao Estado Novo.

Todas as quatro pessoas mencionadas acima nasceram e viveram na zona rural e entraram na escola entre meados da década de 1940 e início da década de 1960. No entanto, entrevistas com moradores(as) de Prudentópolis de gerações mais recentes também trazem informações das experiências do contato com a língua portuguesa apenas a partir da idade escolar.

Claudete, nascida em 1980 e que foi para a escola pela primeira vez em 1987, destacou que na comunidade de Linha Barra Bonita ${ }^{8}$, na zona rural de Prudentópolis, as crianças falavam apenas ucraniano. Ela aprendeu algumas palavras em língua portuguesa apenas quando uma família de não ucranianos foi morar na localidade; quando chegou à escola, falava apenas algumas palavras em português. O idioma com a qual conseguia se comunicar de forma fluente era o ucraniano.

Na conversa com Claudete fica demonstrado que mesmo em gerações mais recentes o monolinguismo em língua ucraniana podia ocorrer. Crianças nascidas na década de 1980, como é o caso dela, ainda podiam chegar à idade escolar sem saber se comunicar em português. A dificuldade da entrevistada aumentou com o fato de que sua professora não era bilíngue português/ucraniano, ou seja, não falava o idioma eslavo.

O fato do contato com o idioma português ocorrer pela primeira vez na escola ou se tornar mais frequente no ambiente escolar não foi, portanto, exclusividade das primeiras gerações de descendentes de imigrantes. Essa situação, portanto, não havia deixado de existir no final dos anos 1980, o que evidencia a primazia da língua ucraniana em Prudentópolis como língua materna. Essa vitalidade linguística, conforme apontado por Ogliari (1999), apesar das mudanças geracionais, inovações tecnológicas e casamentos exogâmicos, atravessou praticamente todo o século XX, mantendo o idioma ucraniano como uma língua viva, ainda que exista evidentemente franca diminuição do seu uso.

Pode parecer que, ao raiar do século XXI, as possibilidades de monolinguismo ucraniano ou a existência de qualquer estranhamento ou choque devido ao uso exclusivo da língua eslava seriam improváveis. No entanto, Simionato (2012, p. 15) relata que no ano de 2009, em Prudentópolis, havia crianças (dezoito casos registrados) que não falavam a língua portuguesa quando foram matriculadas na primeira série do Ensino Fundamental, sendo necessária a intervenção de uma professora bilíngue para que houvesse entendimento.

Em Prudentópolis existem dezenas de escolas, urbanas e rurais, que recebem crianças que iniciam o processo de alfabetização (séries iniciais até o quinto ano, antiga quarta série). Essas escolas são muito heterogêneas tanto em relação ao número de alunos atendidos quanto ao público socioeconômico e étnico que recebem. Algumas escolas da zona rural continuam com o sistema de salas multisseriadas e são localizadas em áreas de difícil acesso. Simionato (2012) ressalta a existência de crianças monolíngues em língua ucraniana, sem especificar de qual escola. Ela apenas pontua que sua pesquisa de campo se deu em uma escola da zona rural.

A ênfase no contato étnico e linguístico dos descendentes de ucranianos no ambiente escolar se justifica na medida em que, nesses espaços, a possibilidade de interação com crianças de diferentes origens é significativa. Com o fim das escolas mantidas exclusivamente pelos grupos

\footnotetext{
80 termo "Linha" é usado para identificar comunidades na zona rural de Prudentópolis. Essa nomeação das localidades no interior de colônias de imigrantes não foi exclusividade do município e nem mesmo do Paraná, sendo utilizado para os outros estados do Sul. Nas áreas destinadas a receber os imigrantes abriase uma estrada, uma linha, e de cada lado dela os lotes eram demarcados (GUÉRIOS, 2007: 134).
} 
imigrantes, as salas de aula passaram a ser o palco dos contatos, traumas, choques, estranhamentos, troca de experiências, aprendizado, bullying, etc. Os locais pedagógicos eram, muitas vezes, o espaço em que meninos e meninas tinham contato com o "outro", uma vez que saíam da companhia dos pais, que podiam falar preferencialmente ou quase exclusivamente em ucraniano em casa.

Nesse sentido, podemos dizer que a escola deixa de ser um lugar arquitetado com uma finalidade específica, delimitada, para se tornar um "espaço praticado", na perspectiva certoniana. Para Certeau os lugares são pré-definidos, uma vez que independem das pessoas que os utilizam; o espaço, ao contrário, é construído pelos atores sociais, que o "moldam" de acordo com seus objetivos e necessidades (CERTEAU, 1994, p. 202).

O ambiente físico fixo, o "lugar escola", é transformado pelas pessoas que o frequentam e torna-se um espaço de conflito, de aprendizagem, de brigas, de socialização, de estranhamentos. $\mathrm{O}$ espaço escolar ultrapassa a simples função outorgada pelo Estado e, nele, as crianças rompem, muitas vezes, a estrita convivência familiar ou religiosa ${ }^{9}$ para travar relações sociais além das rotineiras. No ambiente da escola os alunos vivem experiências que não teriam, caso ficassem restritos aos contatos com indivíduos de seu grupo étnico ${ }^{10}$.

Atualmente, a escola, lugar de supressão das línguas étnicas no passado, pode ser considerada um espaço de manutenção do idioma ucraniano no município, ou de uma tentativa de minimizar a diminuição do seu uso. Em colégios estaduais, principalmente da zona rural, ainda existem cursos de "contra turno" de ucraniano. As aulas de Língua Estrangeira nesses cursos geralmente contemplam aquele idioma, que não faz parte da grade curricular obrigatória. Em um colégio em que há aulas de inglês, por exemplo, pode ser oferecido um curso de ucraniano em horário diferente das aulas normais. Dois estabelecimentos escolares do município de Prudentópolis, o Colégio Estadual do Campo Imaculada Conceição e o Colégio Estadual São João Batista, possuíam até 2019 a disciplina de Língua Ucraniana em suas grades curriculares do "Ensino Fundamental Anos Finais" (conjunto de séries/anos que vai do sexto ao nono ano, antiga quinta a oitava série) ${ }^{11}$.

As experiências vivenciadas no espaço escolar evidenciam que, ao irem para a escola, os meninos e meninas com ascendência ucraniana tinham a oportunidade de estreitar laços sociais com crianças de origens distintas. A partir da frequência à escola e da constatação de que havia um mundo além do doméstico, Claudete (1980) relatou que sentia vergonha quando a mãe falava com ela na língua ucraniana, nas ocasiões em que se deslocavam até a área urbana de Prudentópolis.

Nesse ponto é preciso abrir parênteses, pois o relato nos leva a questionar se a vergonha sentida pela entrevistada não era um motivo para repelir a etnicidade e se recusar a falar o ucraniano. Essa é uma hipótese. Mas não podemos deixar de lembrar que Claudete nasceu em 1980 e viveu a infância e a adolescência em um período em que o contato com pessoas que falavam o português era bem mais comum que em décadas anteriores. Além disso, não aprender a língua ucraniana seria o mesmo que recusar a herança imigrante? Ou seria adotar tal identidade, mas a partir de outros aspectos?

\footnotetext{
9 Lembrando que os descendentes de ucranianos frequentam a sua Igreja, que reforça, entre outros aspectos, o uso do idioma eslavo.

10 A estratégia governamental na Era Vargas era "nacionalizar" a infância (SOUZA, 2011), um eufemismo para referir-se à necessidade das crianças aprenderem o vernáculo nacional e abandonarem progressivamente o idioma trazido pelo grupo imigrante. Dentro dessa perspectiva, a escola era ambiente de supressão das diferenças. Mas esse lugar não se efetiva na realidade: nela, o que ocorre é o espaço sendo praticado pela diferença, e não sua supressão.

11 No ano letivo de 2020 esses dois estabelecimentos passaram a oferecer em suas grades curriculares a disciplina de língua inglesa.
} 
A partir dos estranhamentos e descobertas na escola era possível estabelecer a fronteira entre o "nós" e o "eles" (HALL, 2014; BARTH, 2011). No convívio com "outros" (sendo a professora também um outro, uma vez que não falava a língua eslava) poderiam ocorrer situações distintas: por um lado, poderia haver um reforço da solidariedade étnica e das práticas identitárias; por outro, constatando-se a diferença, poderia existir a negação da condição étnica e a busca de homogeneização para eliminar a diferença ou, pelo menos, minimizá-la. No caso da entrevistada, o que a distinguia era sua ascendência ucraniana e seu conhecimento e domínio da língua. Claudete aprendeu o ucraniano em primeiro lugar e continua dominando o idioma.

Não é possível mensurar o tamanho dos "traumas", das dificuldades enfrentadas pelas pessoas, sejam elas das décadas de 1950, 1980 ou da primeira década do século XXI. O máximo que o pesquisador poderá fazer, ainda que de modo imperfeito, será tentar aquilatá-las a partir das entrevistas. As experiências, traumáticas ou não, ocorreram no contato interétnico de forma concreta. As mudanças no modo de viver das pessoas que foram obrigadas a aprender o português também são passíveis de serem constatadas. Mas o íntimo, o psicológico, é algo fugidio e de difícil apreensão. Além disso, as pessoas não reagem necessariamente da mesma forma diante da mesma situação.

A partir das entrevistas com descendentes dos imigrantes é possível ter acesso às percepções que homens e mulheres possuem acerca de sua história e da maneira como foram os contatos étnicos. Mas, como já salientado, cada indivíduo é afetado de modo diverso pelas circunstâncias e rememora seu passado de um jeito particular. Genoveva (1947), nascida na década de 1940, deixou claro que era difícil aprender o português; já Claudete (1980) trouxe o estranhamento, mas sem necessariamente atribuir sentimentos negativos ao vivenciado.

O tempo das lembranças não é linear e/ou cronológico: "Diante de tantos apelos do momentâneo, os registros de memória dos ucranianos parecem ser a presença do passado que procura no presente apenas sobreviver" (TAMANINI, 2016, p. 65). Tampouco é possível recordar tudo: as reminiscências são selecionadas de forma inconsciente. Esquecer ou lembrar não é um processo de que o indivíduo possui total controle: às vezes o que se quer recordar se perde e o que não se quer rememorar não sai da mente. Somente em casos patológicos o indivíduo é capaz de lembrarse de tudo (DOSSE, 2004, p. 97).

Esse filtro do vivido depende também da idade do indivíduo e das relações interpessoais que travou ao longo da vida:

A visão que cada indivíduo tem do mundo depende não só do lugar social que ele ocupa, da forma como ele se insere na sociedade organizada, mas também do referencial que tem do passado, função também do seu amadurecimento psico-biológico e educacional, ou seja, da sua idade. (NADALIN, 2004, p. 81).

Diante das questões levantadas, constatamos que a questão dos choques étnicos, suas interpretações, expectativas, modos de reagir às experiências, maneiras de relatá-las, variam de acordo com a pessoa e a geração à qual ela pertence.

Perder o domínio da língua pode significar para uns o corte do cordão umbilical com a terra dos ancestrais, que pode ser um procedimento doloroso. Para outros, o contato com a língua portuguesa pode representar uma descoberta, em que o idioma eslavo representa o passado a ser esquecido ou que não tem espaço na "modernidade". Para outros pode ocorrer um misto de ambas as situações. É necessário considerar o fator geracional.

A ucraneidade, expressão utilizada por Tamanini (2017, p. 28) para se referir ao sentimento 
de pertencimento étnico e religioso e aos modos como os ucranianos se autoidentificam e estabelecem a diferença perante o "outro", não possui o mesmo significado e não é explicitada a partir dos mesmos critérios por todas as pessoas e gerações. Dessa forma, cada ucraneidade precisa do referencial temporal no qual foi construída.

\section{Referências}

ACHARD, Pierre. Um ideal monolíngue. In: VERMES, Geneviève; BOUTET, Josiane (Orgs). Multilinguismo. Campinas: Editora da UNICAMP, 1989.

ANDERSON, Benedict R. Comunidades imaginadas: reflexões sobre a origem e a difusão do nacionalismo. [Trad. Denise Bottman]. São Paulo: Companhia das Letras, 2008.

ANDREAZZA, Maria Luiza. Paraíso das delícias: estudo de um grupo imigrante ucraniano 18951995. Curitiba, 1996. 412 f. Tese (Doutorado em História) - Universidade Federal do Paraná, Curitiba, 1996.

BAGNO, Marcos. Preconceito linguístico: o que é, como se faz. São Paulo: Edições Loyola, 2001.

BARTH, Fredrik. Grupos étnicos e suas fronteiras. In: POUIGNAT, Philippe; STREIFF-FENART, Jocelyne. Teorias da etnicidade: seguido de grupos étnicos e suas fronteiras de Fredrik Barth. $2^{a}$ ed. São Paulo: Ed. Unesp, 2011.

BURKO, Vassílio. História de Vassílio. Trad. Doroteu Burko. Curitiba: Imprensa Oficial, 2010.

CERTEAU, Michel de. A invenção do cotidiano: 1. Artes de fazer. Petrópolis, RJ: Vozes, 1994.

COSTA, Lourenço Resende da. Manifestações de Poder e Identidade em torno da língua ucraniana em Prudentópolis. Irati, 2013. 152 f. Dissertação (Mestrado em História) - Universidade Estadual do Centro-Oeste, Irati - PR, 2013.

DECROSSE, Anne. Um mito histórico, a língua materna. In: VERMES, Geneviève; BOUTET, Josiane (Orgs). Multilinguismo. Campinas: Editora da UNICAMP, 1989.

DE HEREDIA, Christine. Do bilinguismo ao falar bilíngue. In: VERMES, Geneviève; BOUTET, Josiane (Orgs). Multilinguismo. Campinas: Editora da UNICAMP, 1989.

DOSSE, François. História e ciências sociais. Bauru, SP: EDUSC, 2004.

GUÉRIOS, Paulo Renato. Memória, identidade e religião entre imigrantes rutenos e seus descendentes no Paraná. Rio de Janeiro, 2007. 299 f. Tese (Doutorado em Antropologia) - Universidade Federal do Rio de Janeiro, Rio de Janeiro, 2007.

HALL, Stuart. Quem precisa de identidade? In: SILVA, Tomaz Tadeu da (Org). Identidade e diferença: a perspectiva dos estudos culturais. 15ª ed. Petrópolis, RJ: Vozes, 2014.

HOBSBAWM, Eric J. Nações e Nacionalismos desde 1780: programa, mito e realidade. $3^{\text {a }}$ Edição. Rio de Janeiro: Paz e Terra, 1990.

JACUMASSO, Tadinei Daniel. Diversidade linguística, cultural e políticas linguísticas: estudo de uma comunidade ucraniana de Irati/PR. Cascavel, 2009, 146 f. Dissertação (Mestrado em Letras) Universidade Estadual do Oeste do Paraná, Cascavel, 2009.

LINHARES, Afonso Miguel; ALENCAR, Claudiana Nogueira de. Repensando o conceito de diglossia à luz de Michel de Certeau. In: Revista de Estudos da Linguagem, Belo Horizonte, v. 24, n. 2, p. 492-518, 2016.

LOPES, Francisco João. O bilinguismo e a problemática da diglossia no processo de Letramento: o caso de Cabo Verde e suas diásporas. In: PAPIA: Revista Brasileira de Estudos do Contato Linguístico. 21 (1), 2011, p. 123-136. 
LUNA, José Marcelo Freitas de. O Português na escola Alemã de Blumenau: da formação à extinção de uma prática - Ensinávamos e aprendíamos a Língua do Brasil. Itajaí/Blumenau: Ed. Da Univali; Ed Furb, 2000.

MARTINY, Franciele Maria; MENONCIN, Camila. O estudo do bilinguismo e da diglossia para uma perspectiva linguística educativa. In: Web-Revista SOCIODIALETO. UEMS - Campo Grande, v. 4, $\mathrm{n}^{\circ}$ 11, nov. 2013.

NADALIN, Sergio Odilon. História e demografia: elementos para um diálogo. Campinas: Abep, 2004. NADALIN, Sergio Odilon. A respeito de uma demografia histórica de contatos culturais. In: Cadernos de História, Belo Horizonte, V. 9, n 11, p. 11-31, 2007.

OGLIARI, Marlene Maria. As condições de resistência e vitalidade de uma língua minoritária no contexto sociolinguístico brasileiro. Florianópolis, 1999. 536 f. Tese (Doutorado em Linguística) Universidade Federal de Santa Catarina, Florianópolis, 1999.

PASSINI, José. Bilinguismo: utopia ou antibabel. Juiz de Fora/Campinas: EDUFJF; Pontes, 1993.

POCHE, Bernard. A construção social da língua In: VERMES, Geneviève; BOUTET, Josiane (Orgs). Multilinguismo. Campinas: Editora da UNICAMP, 1989.

RENK, Valquíria Elita. Aprendi falar português na escola! O processo de nacionalização das escolas étnicas polonesas e ucranianas no Paraná. Curitiba, 2009. 243 f. Tese (Doutorado em Educação) - Universidade Federal do Paraná, Curitiba, 2009.

SEYFERTH, Giralda. A conflituosa história da formação da etnicidade teuto-brasilera. In: FIORE, Neide Almeida; et al (ORG). Etnia e educação: a escola alemã no Brasil e estudos congêneres. Florianópolis/Tubarão: Ed. Da UFSC/Editora Unisul, 2003.

SIMIONATO, Marta Maria. O processo de alfabetização e a diáspora da língua materna na escola: um estudo em contexto de imigração ucraniana no sul do Brasil. Florianópolis, 2012. 291 f. Tese (Doutorado em Educação) - Universidade Federal de Santa Catarina, Florianópolis, 2012.

SKAVRONSKI, Maria Inêz Antonio. Rezar e Benzer: rituais sagrados e identidade étnica em Prudentópolis - PR (1990-2014). Ponta Grossa, 2015. 153 f. Dissertação (Mestrado em História) - Universidade Estadual de Ponta Grossa, Ponta Grossa, 2015.

SOUZA, Sérgio Augusto Freire de. As línguas estrangeiras no contexto da história da educação brasileira: a construção de identidades. Disponível em: http://www.sergiofreire.com.br/HIL.pdf . Acesso em 09-07-2011.

TAMANINI, Paulo Augusto. As reminiscências da diáspora ucraniana na cidade de Papanduva (SC): um passado relembrado. Revista Confluências Culturais, Joinville, v. 5, n. 1, p. 57-68, 2016.

TAMANINI, Paulo Augusto. A prece ucraniana na pressa da cidade: as renegociações das práticas religiosas ucranianas nos espaços da cidade de Curitiba a partir de 1960. Curitiba: CRV, 2017.

VILLAR, Diego. Uma abordagem crítica do conceito de "etnicidade" na obra de Fredrik Barth. Revista Mana, № 10 (1), p. 165-192, 2004.

WACHOWICZ, Ruy Christovam. As escolas da colonização polonesa no Brasil. Curitiba: Champagnat, 2002.

\section{Fontes orais}

BAHRY, Isabel Sydorko [74 anos]. [jan. 2013]. Entrevista realizada pelo autor. Prudentópolis, PR, 18 jan. 2013.

HELLMANN, Sofia Podogurski [60 anos]. [jan. 2013]. Entrevista realizada pelo autor. Prudentópolis, PR, 18 jan. 2013. 
PETRIW, Claudete Maria [37 anos]. [mai. 2017]. Entrevista realizada pelo autor. Prudentópolis, PR, 25 mai. 2017.

TLUMASKI, Teodosio. [66 anos]. [jan. 2013]. Entrevista realizada pelo autor. Prudentópolis, PR, 17 jan. 2013.

VOGIVODA, Genoveva Smah. [65 anos]. [jan. 2013]. Entrevista realizada pelo autor. Prudentópolis, PR, 17 jan. 2013.

Artigo recebido em: 26/06/2020

Artigo aceito em: 04/08/2020 